\title{
Exploring the Service Innovation Strategy of Sharing Economy Based on Ambidextrous Perspective
}

\author{
Hui-Ru CHI ${ }^{* 1}$, Wen-Hong CHIU2 and Jian-Hua YE ${ }^{3}$ \\ ${ }_{1}^{1}$ Assistant Professor, Department of Business Administration, Asia University* \& \\ Consultant, Department of Medical Research, China Medical University Hospital, China Medical \\ University \\ ${ }^{2}$ Associate Professor, Department of Business Administration, Asia University \& \\ Consultant, Department of Medical Research, China Medical University Hospital, China Medical \\ University \\ ${ }^{3}$ Graduate student, Department of Business Administration, Asia University \\ ${ }^{*}$ Corresponding author
}

Keywords: Service Innovation, Ambidextrous, Sharing Economy

\begin{abstract}
Sharing economy" makes more efficient use of unused assets, resources, skills, and time. "Sharing" advocates value comes from the creation of consumers, businesses, and other stakeholders. Look back to the past, many researchers explored the current situation and achievements of industrial value creation. However, few of them explored sharing economy based on ambidextrous perspective. The matrix of exploration and exploitation, virtual and physical frame the analytical framework of ambidextrous perspective. The four quadrants are follow the matrix. The study analyses 30 sharing economic firms. The results are as follows: consumer's capacity rise in the purchase of mobile phone, which improves the use of mobile App desire and opportunity, Brand innovation and marketing threshold to reduce, the innovation cycle to shorten the speed faster. In this case, it is also easier to catch the user's psychological mood and the establishment of consumer groups. Business model innovation in society aspect has become a competitive advantage in the industry. Finally, some practical suggestions are given to the sharing economy and social development.
\end{abstract}

\section{Introduction}

In recent year, we often see the news about development of sharing economy enterprises. For example, Uber, Airbnb, etc. "Sharing economy" makes more efficient use of unused assets, resources, skills, and time. "Sharing economy" makes more efficient use of unused assets, resources, skills, and time. Because of Uber faced to many legal restrictions and barriers in Taiwan, so that we pay attention to information about sharing economy, and we would like to understand its meaning. Therefore, we explore sharing economy enterprises service innovation strategy. The development of the sharing economy industry is not for a long time, but in a short period of time, it has been quickly penetrated into many industries and market segments. The globule value of the sharing economy will increase from $\$ 15$ billion (2013) to \$335 billion (2025), compared with the traditional leasing areas of hotels, car rentals, rentals, rental industrial equipment and so on. In the United States, the sharing economy services is booming, many well-known sharing economy companies 
are from the United States. The United States can be said to the origin of the sharing economy. Whether it is housekeeping or borrowing needs, it has the concept of "sharing" infiltration.

\section{Literature Review}

\section{Service Innovation}

We knew Tax \& Stuart [1] believes that service innovation can be divided into two types: one is the change within the existing service system; the other is the change in the operation process and participants, and it can be known that the service innovation refers not only to the existing service and product. Improving with processes also includes applying science and technology to things that are valuable to society and industry to meet the needs of the market. Furthermore, service innovation has its degree of differentiation, including the introduction of new services, major changes in the provision or delivery of services, and minor restructuring or improvements in existing services [2]. Tax \& Stuart [1] believes that service innovation can be divided into two types: one is the change within the existing service system; the other is the change in the operation process and participants, and it can be known that the service innovation refers not only to the existing service and product. Improving with processes also includes applying science and technology to things that are valuable to society and industry to meet the needs of the market. Furthermore, service innovation has its degree of differentiation, including the introduction of new services, major changes in the provision or delivery of services, and minor restructuring or improvements in existing services [2].

\section{Sharing Economy}

The theory of "sharing economy" was first proposed by Felson (Professor of Sociology from the State University of Texas) and Spaeth (Professor of Sociology from the University of Illinois) [3]. In this paper, two professors use "collaborative consumption" to describe a way of life consumption, the main feature is through a third platform market to achieve point-to-point direct goods and services exchange. The sharing economy grow up is a large-scale revitalization of economic surplus and stimulate the economic benefits of the phenomenon, its existence is committed to solving the problem of economic surplus. Economic surplus is the product of socialized mass production and socialized consumption, which is manifested as idle inventory and idle capacity at the firms level ; At the firms level as idle funds, items and cognitive surpluses. The socialization of idle resources, the sharing of acquaintances to expand the relationship between the unfamiliar groups to enhance the level of mutual trust of members of society to promote the mode of production from a large single center to the center of personalized customization. Because of the concept of sharing, let people have more relaxed life.

\section{Ambidextrous Perspective}

The March [4] theorized that exploration and exploitation are two fundamentally different ways of organizational learning. Exploration concerns learning through knowledge from various sources and adding new variations, while exploitation concerns learning through in-depth revision and recombination of existing knowledge [5].The matrix of exploration and exploitation, virtual and physical frame the analytical framework of ambidextrous perspective. The four quadrants are follow the matrix: Exploration and virtual, exploration and physical, exploitation and physical, exploitation and virtual. 


\section{Method}

This study adopts the case study method [6]. Owyang [7] divide sharing economy into five categories: (a) goods, (b) services, (c) transportation, (d) space, and (e) money. The cases in this study fall in the seven category (i.e., food) of sharing economy. This study follow the "Sharing economy strategy" framework to analysis those 30 sharing firms. In this article, the proposed architecture is based on the analysis of this study and draws the results. We collect the relevant literature, books, news events and other secondary information. And then use case analyses and secondary research analysis. We select thirty firms that offer different services and they are belongs to sharing economy that based on the company's corporate nature, news events, and case stories to analysis. And, the 30 sharing economy firms are follow as Table 1.

Table 1 . The 30 sharing economy firms

\begin{tabular}{|c|c|c|c|c|}
\hline Field & Classification & Company name & Country & Established year \\
\hline \multirow{5}{*}{ Food } & \multirow{2}{*}{ Food Delivery } & Postmates & U.S.A & 2011 \\
\hline & & DoorDash & U.S.A & 2013 \\
\hline & \multirow{2}{*}{ Private kitchen sharing } & EatWith & U.S.A & 2012 \\
\hline & & Feastly & U.S.A & 2013 \\
\hline & Fresh food delivery & Instacart & U.S.A & 2012 \\
\hline Clothing & Rent clothes & Rent the Runway & U.S.A & 2009 \\
\hline \multirow{6}{*}{ Accommodation } & \multirow{2}{*}{ Housekeeping } & Care.com & U.S.A & 2006 \\
\hline & & Handy & U.S.A & 2012 \\
\hline & \multirow{2}{*}{$\begin{array}{l}\text { Tourist accommodation } \\
\text { space }\end{array}$} & Couchsurfing & U.S.A & 2003 \\
\hline & & Airbnb & U.S.A & 2007 \\
\hline & \multirow{2}{*}{ Other space services } & WeWork & U.S.A & 2010 \\
\hline & & MakeSpace & U.S.A & 2013 \\
\hline \multirow{6}{*}{ Transportation } & \multirow{3}{*}{ Car pool } & Uber & U.S.A & 2009 \\
\hline & & Lyft & U.S.A & 2012 \\
\hline & & DiDi Chuxing & Chain & 2012 \\
\hline & \multirow{2}{*}{ Car rental } & Zipcar & U.S.A & 2000 \\
\hline & & Car2go & Germany & 2008 \\
\hline & Parking service & JustPark & U.K & 2006 \\
\hline \multirow{3}{*}{ Education } & \multirow{2}{*}{ Skill sharing } & SkillShare & U.S.A & 2010 \\
\hline & & TakeLessons & U.S.A & 2006 \\
\hline & Course education & Coursera & U.S.A & 2012 \\
\hline \multirow{3}{*}{ Recreation } & Flower delivery & Bloomthat & U.S.A & 2012 \\
\hline & Care dog services & DogVacay & U.S.A & 2012 \\
\hline & Sports & ClassPass & U.S.A & 2013 \\
\hline \multirow{6}{*}{ other } & Task outsourcing & TaskRabbit & U.S.A & 2008 \\
\hline & Credit investigation & Onfido & U.K & 2012 \\
\hline & \multirow{2}{*}{ Finance } & Zopa & U.K & 2004 \\
\hline & & Lending Club & U.S.A & 2006 \\
\hline & Medical & PatientsLikeMe & U.S.A & 2004 \\
\hline & Items & Neighboorgoods & U.S.A & 2009 \\
\hline
\end{tabular}

(Source: The Study of Organized.) 


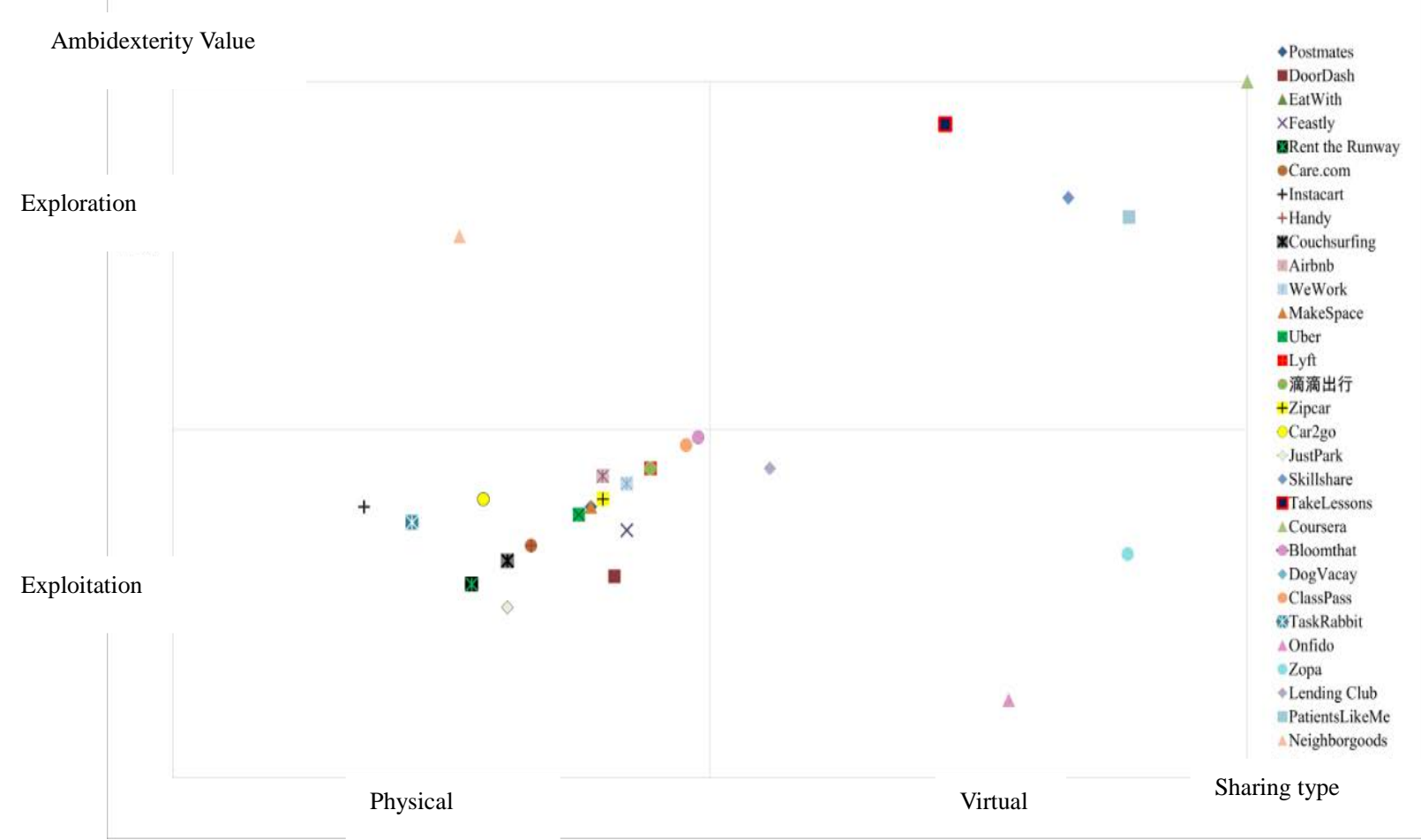

Figure 1 . The ambidexterity and sharing economy types

\section{Results and Concussion}

The results of the study found that there are several important aspects of sharing economy, innovation and development of science and technology, the concept of non-waste and changes in social values. Now consumer's capacity rise in the purchase of mobile phone, which improves the use of mobile App desire and opportunity, Brand innovation and marketing threshold to reduce, the innovation cycle to shorten the speed faster. In this case, it is also easier to catch the user's psychological mood and the establishment of consumer groups. Most of the 30 sharing economy firm's service models captured in this study are companies that provide entity services. In the past, people are still used to using physical item, and enjoy its service. Sharing economy using the internet platform to make people together, not only make sharing economy more generally appear in our life, but also allow people to more easily in purchase or rent. And, the matrix including the 4 quadrants are follow the figure 1. Finally, some practical suggestions are given to the sharing economy and social development on the industries.

\section{Reference}

[1] Tax, S., Brown S., 1998. Recovering and learning from service failure. Sloan Management Review, 49 (1), Autumn, 75-88.

[2] Gallouj, F., Weinstein, O., 1997. Innovation in services. Research Policy 26 (4/5), 537-556.

[3]Felson, Marcus and Joe L. Spaeth (1978), "Community Structure and Collaborative Consumption: a Routine Activity Approach,” American Behavioral Scientist, 21(4), 614-624. 
[4] March, J. G. (1991) Exploration and exploitation in organizational learning. Organization Science, 2, 71- 87.

[5] Katila, R. and G. Ahuja. (2002), Something old, something new: A longitudinal study of search behavior and new product introduction. Academy of Management Journal,45(1), 183-194.

[6] Yin, R. K. 2014, Case Study Research: Design and Methods (Fifth Edition), SAGE Publications, Inc.

[7]Owyang, Jeremiah (2014), "Sharing is the New Buying: How to Win in the Collaborative

Economy," (accessed Feb. 20, 2018), [available at
http://www.slideshare.net/jeremiah_owyang/sharingnewbuying]. 